\title{
PENGARUH BUDAYA ORGANISASI, GAYA KEPEMIMPINAN, DAN KEPUASAN KERJA TERHADAP KINERJA KEPALA SEKOLAH MENENGAH ATAS DI JAKARTA TIMUR
}

\author{
Sutji Harijanto*
}

\begin{abstract}
This survey focuses on the effects of organizational culture, leadership style and job satisfaction on senior high school principals' performance in East Jakarta. Sixty schools were selected randomly as a unit of analysis and data were analyzed by path analysis. Findings of the research indicated direct effects of: 1) Organizational culture and leadership style on job satisfaction, and 2) Organizational culture, leadership style, and job satisfaction on the principal's performance. The results also showed indirect effect of organizational culture and leadership style on the principal's performance through job satisfaction. In addition, job satisfaction was the most dominant variable that effected senior high school principal's performance.
\end{abstract}

Keywords: Organizational culture, leadership style, job satisfaction, and performance.

\section{PENDAHULUAN}

Menurut Human Development Index tahun 2007 yang diterbitkan oleh United Nations Development Programme, kualitas sumberdaya manusia Indonesia menempati peringkat 107 dari 177 negara. Sedangkan Malaysia menempati peringkat 63, yang berarti sistem pendidikan di Malaysia untuk mengembangkan kualitas sumber-daya manusianya lebih baik dari pada Indonesia. Selanjutnya Kinerja Sekolah rata-rata di Indonesia juga rendah, berdasarkan sumber dari Programme for International Student Assessment (PISA) tahun 2006, mutu akademik antar bangsa menunjukkan bahwa dari 57 negara yang disurvei untuk mata pelajaran Matematika dan Ilmu Pengetahuan Alam, Indonesia masing-masing hanya menempati peringkat 50, sedangkan kemampuan membaca menempati peringkat 48. Hasil tersebut wajar mengingat cikal bakal beberapa guru senior, wakil dan kepala sekolah saat ini merupakan sumbangan input perekrutan guru 10 tahun yang lalu. Fakta di lapangan menunjukkan banyak guru yang tidak memenuhi kualifikasi, karena belum memiliki kompetensi profesional, kompetensi pedagogik, kompetensi kepribadian, dan kompetensi sosial (Sumber: Direktorat P2TK dan KPT, Ditjen Dikti, Depdiknas RI, Standar Kompetensi Guru Pemula PGSMK, 2004). Pernyataan di atas senada dengan laporan Statistik Persekolahan SMA yang diterbitkan oleh Pusat Statistik Pendidikan, Badan Penelitian dan Pengembangan Departemen Pendidikan Nasional tahun 2006 yakni dari 267.419 guru SMA (negeri dan swata) seluruh Indonesia hanya 199.970 guru $(74,78 \%$ ) yang masuk kategori layak (guru yang berijazah Sarjana keguruan dan ijazah di atasnya), sedangkan sisanya 25,22 \% tidak layak.

Khusus mengenai kinerja kepala Sekolah Menengah Atas di Kota Jakarta Timur yang menjadi sasaran penelitian, wilayah ini terbagi menjadi 10 kecamatan dan memiliki populasi SMA sebanyak 146 sekolah, yang mampu menampung siswa sebanyak 57.013 anak. Kinerja Kepala SMA di Jakarta Timur pada tahun 2008 dapat dikemukakan dalam 2 (dua) aspek, yakni: (1) pemerataan pendidikan, (2) peningkatan mutu. Terkait dengan pemerataan pendidikan, Angka Partisipasi Kasar (APK) SMA

\footnotetext{
* Kepala Seksi Pelaksanaan Kurikulum Direktorat PSLB, Audit Internal ISO 9001:2008 Direktorat PSLB, Staf Pengajar pada STMIK Muhammadiyah Jakarta
} 
pada tahun 2008 baru mencapai 42\%, sedangkan Angka Partisipasi Murni (APM) 29\%. Rasio siswa per sekolah 1:867 artinya setiap SMA jumlah rata-rata siswanya sebanyak 867 siswa, rasio siswa per kelas 1:39 yang berarti setiap kelas jumlah siswanya rata-rata sebanyak 39, rasio siswa per guru 1:14 artinya setiap guru rata-rata mengajar siswa sebanyak 14 anak. Sedangkan terkait peningkatan mutu, dikala pemerintah mencanangkan standar nilai minimal kelulusan ujian nasional untuk jenjang pendidikan dasar dan menengah tahun pelajaran 2008/2009 sebesar 5,50, jumlah kelulusan yang dicapai siswa SMA di Kota Jakarta Timur sebesar 98,06\%, dengan nilai hasil ujian nasional rata-rata 5,74 (rendah). Di sektor tenaga pendidik dari 4.690 guru telah diidentifikasi sebanyak 61,87\% termasuk dalam kategori layak mengajar, dan 38,13\% masuk kategori tidak layak mengajar.

Fakta di atas merupakan beberapa indikasi rendahnya kinerja kepala SMA di Jakarta Timur. Rendahnya kinerja tersebut, tidak terlepas dari rendahnya input siswa, rendahnya kualitas proses belajar mengajar, kualifikasi guru rendah, rendahnya motivasi kerja, iklim kerja, gaya kepemimpinan kepala sekolah tidak sesuai untuk mempengaruhi bawahannya, kurang tepatnya budaya organisasi yang diterapkan oleh warga sekolah dan lainnya. Jika hal ini tidak diperhatikan, maka dapat menimbulkan distorsi yang akan menghambat proses perkembangan pendidikan di Jakarta Timur, yang sulit untuk bersaing di forum nasional maupun internasional. Mengingat pada tahun 2008/2009 banyak permasalahan yang berakibat rendahnya Kinerja Kepala SMA di Jakarta Timur, dengan indikasi (1) APK dan APM SMA masih rendah yakni $42 \%$ dan 29\% (2) Nilai Rata-rata Ujian Nasional SMA tahun 2008/2009 baru mencapai 5.74 (3) Persentase Guru yang tidak layak mengajar masih tinggi sebesar 38,13 \% (4) Persentase kesesuaian guru mata pelajaran untuk mengajar rata-rata baru 6\% (5) Angka putus sekolah masih cukup tinggi sebesar 1,46\%, maka perlu dilakukan penelitian tentang kinerja Kepala SMA di Jakarta Timur.

\section{Kinerja}

Robbins (2005:254) menyatakan bahwa Keberhasilan dalam melakukan sesuatu pekerjaan sangat ditentukan oleh kinerja. Sementara itu Harsey, Blanchard dan Johnson (1996:92-93) mengemukakan bahwa kinerja adalah hasil dari suatu aktivitas atau pekerjaan. Sedangkan Bernardin dan Russell dalam buku Ruky (2006:15) mengemukakan "performance is the record of outcome produced on a specified job function or activity during a

specified time period." Mengacu pengertian tersebut terkandung tiga aspek yang perlu dipahami oleh setiap pemimpin suatu organisasi dan bawahannya, yakni (1) Kejelasan tugas yang menjadi tanggungjawab, (2) Kejelasan hasil yang diharapkan oleh organisasi, dan (3) Waktu yang diperlukan untuk menyelesaikan pekerjaan. Senada dengan pendapat di atas, Handoko (2000:11) mengemukakan bahwa "kinerja sebagai proses dimana organisasi mengevaluasi atau menilai prestasi karyawan". Kemudian diperkuat dengan pendapat Prawiro Suntoro (1999:121) bahwa "kinerja adalah hasil kerja yang dapat dicapai seseorang atau sekelompok orang dalam suatu organisasi dalam rangka mencapai tujuan organisasi dalam periode tertentu.

Selanjutnya, Bowin and Harvey (1996:140) menyatakan bahwa "performance may be defined as the accomplishment of an employee or manager assigned duties and the outcomes produced on a job function or activity during specied time period." Di dalam definisi tersebut terkandung makna bahwa kinerja berhubungan dengan faktor prestasi, karena terkait 
dengan kesungguhan dalam pekerjaan. Kata kinerja juga merujuk pada hasil kerja dalam penyelesaian pekerjan, penanganan atau pelaksanaan suatu tugas. Bates dan Hoeton, dikutip oleh Amstrong dan Baron (1998:15) mengemukakan bahwa kinerja sebagai suatu hasil kerja atau tingkah laku. Dengan demikian, istilah kinerja akan mengarah kepada dua hal, yaitu proses dan hasil kerja yang dicapai. Kinerja merupakan suatu tindakan dari proses yang melibatkan berbagai macam komponen aktivitas. Kinerja tidak hanya dipandang sebagai hasil yang terjadi pada titik tertentu di kurun waktu tertentu. Sedangkan Robbins (2005:231) menyatakan kinerja merupakan tolak ukur keberhasilan dalam melakukan sesuatu pekerjaan. Pendapat lain disampaikan oleh Richard M. Hodgetts \& Donald F. Kuratko (1988:438) bahwa kinerja berkaitan dengan seberapa baik seseorang melakukan pekerjaannya. Dikaitkan dengan peran individu dalam organisasi, kinerja adalah serangkaian perilaku atau kegiatan individu yang sesuai dengan harapan atau keinginan organisasi tempat ia bekerja.

Pendapat lain disampaikan oleh Colquitt, LePine dan Wesson (2009:37) bahwa kinerja secara formal digambarkan sebagai nilai dari himpunan perilaku-perilaku karyawan yang mendukung, baik secara positif maupun negatif demi mencapai tujuan organisasi. Robbins dan Judge (2009:629-630) menyatakan ada tiga indikator kinerja, yaitu (1) Hasil kerja individu (individual task outcomes), (2) Perilaku yang sering dilakukan (behaviors) dan (3) Karakter individual (traits). Hasil kerja individual tergantung pada perilaku seseorang dalam melakukan pekerjaannya. Perilaku disini adalah perilaku yang berkaitan dengan tugas yang harus kerjakan. Sedangkan karakter individu merupakan sifat bawaan seseorang yang mencakup antara lain percaya diri, dapat diandalkan, dapat bekerjasama, berpengalaman. Namun demikian, pengukuran kinerja lebih baik ditekankan pada kriteria perilaku daripada kriteria karakteristik.

Sementara itu Heyness (1984:134-135) menyatakan bahwa dalam mengevaluasi perilaku seseorang yang berkaitan dengan kinerjanya, maka yang perlu diperhatikan adalah metode kerja, prosedur kerja dan kebiasaan kerja. Dengan demikian, perilaku yang dapat dievaluasi adalah: (1) Kepemimpinan; (2) Perencanaan; (3) Pengorganisasian; (4) Penentuan perioritas; (5) Pendelegasian; (6) Pengontrolan; (7) Pemecahan masalah; (8) Pembuatan keputusan; (9) Komunikasi langsung; (10) Komunikasi tertulis; (11) Kemampuan administratif; (12) Kemampuan berhubungan dengan orang lain; (13) Keselamatan kerja; (14) Kebersihan; (15) Ketepatan waktu; (16) Kehadiran.

Dengan demikian, kinerja kepala sekolah mengisyaratkan kecakapan konsep, kecakapan kemanusiaan dan kecakapan teknis. Kinerja kepala sekolah juga dikaitkan dengan perannya sebagai agen penghubung sekolah dengan guru, siswa dan masyarakat; pemimpin kegiatan pembelajaran; katalisator untuk mencapai prestasi sekolah dan pembaharuan; penjaga ketertiban sekolah; dan manajer berbagai sumber yang ada di sekolah. Kinerja kepala sekolah juga dinilai melalui metode kerja, prosedur kerja dan kebiasaan kerja.

Dari beberapa konsep di atas, dapat disintesiskan bahwa kinerja adalah unjuk kerja yang dilakukan oleh kepala sekolah dalam rangka pelaksanaan tugas dan fungsinya untuk mencapai tujuan organisasi, dengan indikator : merencanakan program kerja, mampu menyelesaikan tugas dengan baik, tanggap terhadap keluhan dan prestasi, kerjasama, pengelolaan administrasi, dan evaluasi terhadap program kerja yang telah dilaksanakan 


\section{Budaya Organisasi}

Robbins dan Judge (2009:585) memberi batasan tentang budaya organisasi sebagai berikut: "organizational culture refers to a system of shared meaning held by members that distinguishes the organization from other organization". Artinya budaya organisasi mengacu ke suatu sistem makna bersama yang dibentuk oleh anggota-anggotanya sekaligus pembeda organisasi. Sedangkan, menurut Luthans (2008:74) budaya organisasi adalah "a pattern of basic assumption invented, discovered, or developed by a given group as it learns to cope with as problems of external adaption and internal integration that has worked well enough to be considered valuable and, therefore, to be taught to new members as the correct way to perceive, think, and feed in relation to those problems". Dari definisi ini tampaknya budaya organisasi sesungguhnya tumbuh karena diciptakan dan dikembangkan oleh individuindividu yang bekerja dalam suatu organisasi, dan diterima sebagai nilai-nilai yang harus dipertahankan dan diturunkan kepada setiap anggota baru. Nilai-nilai tersebut digunakan sebagai pedoman bagi setiap anggota selama mereka berada dalam lingkungan organisasi tersebut dan dapat dianggap sebagai ciri khas yang membedakan sebuah organisasi dengan organisasi lainnya.

Selanjutnya Jones (2001:130-131) mengemukakan, "organizational culture is the set of shared values and norms that controls organization members interactions with each other and with people outside the organization. Values is general criteria, standards, or guiding principles that people use the determine which types of behaviors, events, situations, and outcomes are desirable or undesirable. Norms is standards or styles of behavior that are considered acceptable or typical for a group of people". Dalam definisi itu terkandung maksud bahwa budaya organisasi merupakan seperangkat nilai dan norma yang tersebar luas yang dapat mengontrol interaksi antar anggota organisasi maupun anggota organisasi dengan orang-orang yang ada di luar organisasi. Nilai adalah standar yang bersifat umum berisikan prinsip-prinsip yang dianggap baik dan tidak baik dilakukan. Sedangkan norma adalah standar perilaku

yang boleh atau bahkan harus dilakukan dan yang tidak boleh dilakukan anggota organisasi. Sementara itu, Gibson, et al (2006:31) menyatakan bahwa "organizational culture is what the employees perceive and how this perception creates a pattern of beliefs, values, and expectations". Sehingga di dalamnya mengandung maksud bahwa apa yang dipahami oleh karyawan dan bagaimana persepsi itu menciptakan sebuah pola dari keyakinan.

Kemudian dalam perkembangannya Kreitner dan Kinicki (2008:42) menyatakan bahwa "organizational culture is the set of shared, taken for granted implicit assumptions that a group holds and that determines how it perceives, think about, and reacts to its various environments". Di mana di dalam pernyataan tersebut memiliki arti budaya organisasi merupakan suatu wujud anggapan yang dimiliki, diterima secara implisit oleh kelompok dan menentukan bagaimana kelompok tersebut rasakan, pikirkan dan bereaksi terhadap

lingkungannya yang beraneka ragam. Lain lagi yang dikemukakan oleh Schein (2004:17), “organisasi merupakan suatu pola dari seperangkat asumsi-asumsi dasar yang digunakan oleh anggotanya dalam menyelesaikan masalah-masalah adaptasi internal maupun eksternal yang berhasil dengan baik dan dianggap sah. Kemudian diajarkan kepada anggota baru sebagai suatu cara yang tepat dalam merasakan, memandang dan menganalisa masalah".

Dari beberapa konsep di atas, dapat disintesiskan budaya organisasi adalah suatu pedoman yang dianut organisasi mencakup nilai-nilai, norma, prinsip-prinsip dan 
peraturan yang berlaku di dalam organisasi untuk menentukan bagaimana para anggota organisasi bertindak dengan indikator: melakukan inisiatif dalam proses pengambilan keputusan, toleransi terhadap tindakan dan konflik, membimbing bawahan, melakukan pengawasan, menjalin kerjasama, memberi penghargaan, meminta pengarahan dan dukungan dari atasan.

\section{Gaya Kepemimpinan}

Menurut Weihrich dan Koontz (2005:396) "leadership is the art or process of influencing people so that they will strive willingly and anthusiascally toward the achievement of group goals". Ini menunjukkan kepemimpinan merupakan suatu seni atau proses mempengaruhi orang sehingga mereka akan senang berusaha dan antusias mencapai tujuan kelompok. Sementara itu Kreitner dan Kinicki (2008:347) menyatakan bahwa "leadership as a social influence process in which the leader seeks the voluntary participation of subordinates in an effort to reach organizational goals". Dengan demikian, pemimpin harus melakukan pengaruh sosial untuk mencari partisipasi sukarela dari bawahan dalam usaha untuk mencapai tujuan organisasi.

Selanjunya style/gaya dapat diartikan sebagai sikap, gerakan, tingkah laku, gerak gerik, kekuatan, kesanggupan untuk berbuat baik. Menurut Rivai (2003:64) sebagai berikut : (1) Gaya kepemimpinan adalah pola menyeluruh dari tindakan seorang pemimpin baik yang tampak maupun yang tidak tampak oleh bawahannya, (2) Gaya kepemimpinan menggambarkan kombinasi yang konsisten dari falsafah, keterampilan, sifat, dan sikap yang mendasari perilaku seseorang, (3) Gaya kepemimpinan menunjukkan secara langsung maupun tidak langsung tentang keyakinan seorang pimpinan terhadap kemampuan bawahannya, (4) Gaya kepemimpinan adalah perilaku dan strategi, sebagai hasil kombinasi dari falsafah, keterampilan, sifat, sikap, yang sering diterapkan seorang pemimpin ketika ia mencoba mempengaruhi kinerja bawahannya, (5) Gaya kepemimpinan merupakan dasar dalam mengklasifikasikan tipe kepimimpinan, (6) Gaya kepemimpinan yang paling tepat/sesuai adalah suatu gaya yang dapat memaksimumkan produktivitas, kepuasan kerja, pertumbuhan dan mudah menyesuaikan dengan segala situasi. Sementara itu Matondang (2008:5) mengemukakan gaya kepemimpinan adalah "pola sikap dan perilaku yang ditampilkan dalam proses mempengaruhi orang lain". Lebih lanjut dia mengutarakan gaya kepemimpinan banyak ragamnya antara lain (1) telling (2) consultating, (3) participating, dan (4) delegating. Lain lagi pendapat Thoha (2001:265) bahwa gaya kepemimpinan merupakan "norma perilaku yang digunakan oleh seseorang pada saat orang tersebut mempengaruhi perilaku orang lain seperti yang ia lihat".

Dari beberapa konsep di atas, dapat disintesiskan bahwa gaya kepemimpinan adalah pola perilaku yang ditunjukkan oleh kepala sekolah dalam menerapkan kepemimpinannya untuk mencapai tujuan organisasi dengan indikator: memberdayakan bawahan, memberi bimbingan, peduli terhadap bawahan, melibatkan bawahan dalam pengambilan keputusan, menciptakan suasana kerja yang kondusif, dan memperhatikan karir bawahan.

\section{Kepuasan Kerja}

Robbins dan Judge (2007:79) menyatakan "job satisfaction as a positive feeling about one's job resulting from an evaluation of its characteristics". Pendapat ini mengandung makna bahwa kepuasaan kerja sebagai suatu perasaan positif tentang pekerjaan seseorang yang merupakan hasil evaluasi karakteristik. Sementara itu kepuasan kerja 
dikaitkan dengan psikologi yang disampaikan oleh Blum yang dikutip oleh Anoraga (2006:82) bahwa "Kepuasan kerja merupakan sikap umum yang merupakan hasil dari beberapa sikap khusus terhadap faktor-faktor pekerjaan, penyesuaian diri dan hubungan sosial individu di luar kerja". Sedangkan Tyson dan Jackson (2000:29) mengkaitkan kepuasan dengan perilaku kerja, maka kepuasan kerja berada di satu sisi secara seimbang dapat dikaitkan dengan (1) Rasa suka dan tidak suka; (2) Kecelakaan kerja (ceroboh-hati-hati); (3) Kegembiraan-kesedihan; (4) Rajin/tepat waktumalas/terlambat; (5) Hadir dan tidak hadir kerja; (6) Turnover dan sebagainya.

Selanjutnya Wexley dan Yukl (2005:129) menyatakan bahwa "kepuasan kerja adalah cara seorang pekerja merasakan pekerjaannya. Kepuasan kerja merupakan generalisasi sikap-sikap terhadap pekerjaan yang didasarkan atas aspek-aspek pekerjaanya bermacam-macam. Kepuasan kerja dipengaruhi oleh beberapa aspek pekerjaan, meliputi : upah/gaji, kondisi kerja, pengawasan, teman kerja, materi pekerjaan, jaminan kerja, dan kesempatan untuk maju". Berdasarkan pernyataan tersebut, kepuasan kerja dapat dilihat dari berbagai sudut pandang, yaitu: (1) Ungkapan perasaan; (2) Imbalan kerja untuk memenuhi kebutuhan; (3) Reaksi berupa tindakan. Pengertian dimaksud menggambarkan bahwa banyak faktor yang mempengaruhi dan dipengaruhi oleh kepuasan kerja. Hal tersebut terjadi karena rasa ketidakpuasan akan muncul sebagai sikap dan tindakan termasuk juga dalam semangat seseorang untuk bekerja, konsentrasi

orang dalam bekerja dan lainnya. Kepuasan kerja tidak hanya berkaitan dengan kondisi pekerjaan, tetapi kepribadian juga memainkan sebuah peran.

Kemudian Robbins dan Coulter (2007: 53) menyatakan kepuasan kerja "merupakan sikap umum seorang karyawan terhadap pekerjaannya". Orang yang kepuasan kerjanya tinggi akan bersikap positif terhadap pekerjaannya, sedangkan orang yang kecewa terhadap pekerjaannya akan bersikap negatif. Jika dikaitkan dengan kondisi sekolah, maka pengertian tersebut dapat dijelaskan bahwa kepemimpinan sekolah mempunyai peranan sangat besar dalam menciptakan kepuasan kerja guru. Kepala sekolah merupakan pemimpin tunggal di sekolah dengan kekuasaannya merupakan kunci dalam menciptakan kepuasan yang disebabkan oleh faktor eksternal.

Dubrin dikutip Fraser (2000:47-48) berpendapat terdapat tiga faktor pemuas kerja yaitu: (1) Isi pekerjaan mencakup kemampuan mengkoordinasi gerak, mengutarakan pendapat secara intelegen, kreatif dan fleksibel dalam menanggapi setiap masalah, (2)

Lingkungan struktur pekerjaan meliputi sistem imbalan, lokasi pekerjaan, sifat beban kerja serta kelengkapan peralatan, (3) Kebutuhan individu dari pemegang jabatan atau pelaku pekerjaan, yaitu: faktor-faktor lain tanpa wujud) yang mencakup kebijakan dalam menentukan sistem kerja, prospek kenaikan jenjang, dan lain sebagainya. Lebih lanjut, Dubrin menyampaikan bahwa faktor yang mempengaruhi kepuasan seseorang ditentukan oleh 3 (tiga) faktor, yaitu: (1) Organisasi, (2) Kelompok, dan (3) Individu. Ketiga faktor tersebut mempunyai andil yang sama besarnya dalam menentukan kepuasan kerja, jika salah satu dari ketiga faktor tersebut kurang terpenuhi maka kepuasan kerja menjadi rendah, demikian pula dengan faktor lainnya. Sementara itu George \& Jones (2002:81) mengemukakan faktor-faktor utama yang mempengaruhi kepuasan kerja dapat dibagi atas 4 (empat) kategori, yaitu a) Kepribadian, b) Situasi pekerjaan, c) Pengaruh sosial, dan d) Nilai-nilai (value). Sedangkan Noe (2000:365-370) menyatakan sumber kepuasan kerja berasal dari (a) Sifat pribadi seseorang, (b) Tugas dan peran, (c) Atasan dan rekan kerja, dan (d) Imbalan yang didapat. Mengacu hal 
tersebut, maka yang perlu dipahami adalah bahwa kepuasan kerja bukan merupakan kemutlakan tetapi bernilai relatif.

Atas dasar teori-teori yang dikemukakan di atas, maka yang dimaksud kepuasan kerja dalam penelitian ini adalah terpenuhinya harapan dan kebutuhan kepala sekolah dengan indikator: senang dalam melaksanakan tugas, memberi dukungan teman sekerja, bertanggung jawab terhadap tugas, disiplin dan sabar dalam melaksanakan tugas, menghargai hasil pekerjaan, memberi imbalan yang sesuai, dan menciptakan kompetisi.

\section{METODE}

Penelitian dilaksanakan pada Sekolah Menengah Atas di Kota Jakarta Timur, Propinsi Daerah Khusus Ibukota Jakarta. Penelitian dilaksanakan selama 3 bulan dimulai dari Februari sampai dengan Mei 2009. Penelitian ini menggunakan metode survey dengan pendekatan kausal. Dalam pendekatan kausal digunakan teknik analisis data analisis jalur (path analysis). Teknik pengambilan sampel yang digunakan adalah Simple Random Sampling yaitu penarikan sampel yang dilakukan secara acak sederhana. Dengan menggunakan teknik ini memperoleh 60 sampel dari populasi terjangkau sebanyak 146.

\section{HASIL DAN PEMBAHASAN}

Berkenaan dengan hasil pengujian hipotesis penelitian yang sebelumnya dilakukan uji prasyarat analisis data maka hasil penelitian menunjukkan terdapat pengaruh langsung budaya organisasi terhadap kepuasan kerja. Hal ini sesuai dengan model teoretik yang dinyatakan oleh Colquitt, LePine dan Wesson (2009:37) dan didukung dengan pernyataan Robbins (2002:265) bahwa budaya organisasi akan dapat mempengaruhi kinerja dan kepuasan kerja bila dilihat dari dimensi manajemen, anggota secara kelompok dan anggota secara individual. Besar koefisien jalur antara budaya organisasi terhadap kepuasan kerja sebesar $\rho_{31}=0,458$. Besar pengaruh budaya organisasi terhadap kepuasan kerja adalah 0,2097.

Gaya kepemimpinan berpengaruh secara langsung terhadap kepuasan kerja. Besar koefisien jalur antara gaya kepemimpinan terhadap kepuasan kerja adalah $\rho_{32}=$ 0,431 . Besar pengaruh gaya kepemimpinan terhadap kepuasan kerja adalah 0,1857 . Hasil ini

menunjukkan bahwa pengaruh gaya kepemimpinan dapat memberikan kepuasan kerja individu. Temuan ini mendukung pernyaatan Colquit, LePine, dan Wesson (2009:37) bahwa gaya kepemimpinan yang baik akan dapat memberikan kepuasan kerja bagi seseorang. Dengan gaya kepemimpinan menciptakan suasana hubungan yang akrab sehingga bawahan dan atasan terjadi saling pengertian yang baik, kerjasama yang baik, sehingga pekerjaan atau tugas organisasi dapat dijalankan dengan lancar tanpa hambatan yang berarti, sehingga tujuan organisasi tercapai sesuai rencana yang sudah ditetapkan sebelumnya dan pada akhirnya memberikan kepuasan kerja karena tujuan tercapai dengan baik.

Budaya organisasi berpengaruh terhadap kinerja. Besar koefisien jalur antara budaya organisasi terhadap kinerja adalah $\rho_{41}=0,138$. Besar pengaruh langsung budaya organisasi terhadap kinerja adalah sebesar 0,019. Walaupun, hasil ini menunjukkan pengaruhnya kecil, namun hasil ini membuktikan bahwa budaya organisasi dapat meningkatkan kinerja. Budaya sangat mempengaruhi suasana kerja dalam organisasi. Budaya organisasi adalah perwujudan sehari-hari dari nilai dan tradisi yang mendasari 
organisasi tersebut yang akan terlihat bagaimana pegawai berperilaku, harapan pegawai terhadap organisasi dan sebaliknya, serta apa yang dianggap wajar dalam hal bagaimana pegawai melaksanakan pekerjaannya. Temuan penelitian ini mendukung pernyataan Mondy dan Noe terdapat pengaruh budaya organisasi atau budaya perusahaan terhadap kinerja karyawan ("A firm's culture has an impact on employee job satisfaction as well as on the level and quality of employee performance"). Lebih lanjut, Robbins (2002:24) menyatakan budaya organisasi adalah perangkat yang penting di dalam peningkatan kinerja organisasi.

Gaya kepemimpinan berpengaruh secara langsung terhadap kinerja. Besar koefisien jalur antara gaya kepemimpinan terhadap kinerja adalah $\rho_{42}=0,215$. Besar pengaruh gaya kepemimpinan terhadap kinerja adalah 0,0462. Hasil ini menunjukkan bahwa pengaruh gaya kepemimpinan dapat meningkatkan kinerja individu. Temuan ini mendukung pernyaatan Robbins dan Coulter (2007:193) bahwa gaya kepemimpinan yang baik akan dapat meningkatkan kinerja seseorang. Dengan gaya kepemimpinan menciptakan suasana hubungan yang akrab antara bawahan dan atasan dapat melakukan kerjasama

yang baik, sehingga menimbulkan kesadaran untuk melakukan pekerjaan atau tugas dengan sebaik-baiknya untuk mencapai tujuan yang diharapkan. Bila pekerjaan tersebut dapat dilakukkan dengan baik, ini menunjukkan kinerjanya semakin baik.

Kepuasan kerja berpengaruh terhadap kinerja. Besar koefisien jalur antara kepuasan kerja terhadap kinerja ditunjukan dengan $\rho_{43}=0,412$. Besar pengaruh langsung kepuasan kerja terhadap kinerja adalah sebesar 0,3819. Pengaruh kepuasan kerja terhadap kinerja sangat besar. Temuan ini membuktikan bahwa kepuasan kerja dapat meningkatkan kinerja. Temuan ini mendukung pernyataan Band (1991:23) yang mengungkapkan kepuasan kerja merupakan suatu tingkatan di mana kebutuhan, keinginan dan harapan dari pegawai dapat terpenuhi yang akan meningkatkan kinerja. Lebih lanjut dinyatakan Mowen (1995:25) bahwa faktor yang paling penting untuk menciptakan kepuasan kerja adalah kinerja. Di samping itu, pernyataan Vroom dengan teori motivasinya memandang bahwa (1) orang termotivasi untuk melakukan sesuatu yang mereka rasa memiliki keuntungan tinggi yang mengarahkan pada reward (penghargaan) yang mereka nilai, (2)

minat terhadap kepuasan kerja berasal dari kaitan yang rendah tetapi konsisten dengan kinerja. Salah satu kemungkinan bahwa kepuasan meningkatkan kinerja. Dengan menggunakan teori motivasi Path Goal, Vroom telah menunjukkan bahwa kepuasan kerja dan kinerja disebabkan oleh hal yang sungguh berbeda: "kepuasan kerja sangat dipengaruhi oleh sejumlah reward yang diterima karyawan dari pekerjaannya dan tingkat kinerja sangat dipengaruhi oleh dasar pencapaian reward. Sesuai dengan pendapat Gibson et al. (2006: 110) yang menyatakan Kepuasan kerja adalah suatu sikap individu tentang pekerjaannya. Selanjutnya, dalam penelitiannya terjadi perdebatan dan kontroversi mengenai pengaruh antara kepuasan kerja terhadap kinerja sehingga diperoleh tiga alternatif argumen sudut pandang, yaitu (1) kepuasan menyebabkan kinerja (satisfaction causes performance), (2) kinerja menyebabkan kepuasan (performance causes satisfaction), ganjaran menyebabkan kepuasan dan kinerja (reward satisfaction causes performance).

Selain itu, hasil temuan penelitian diperoleh budaya organisasi berpengaruh terhadap kinerja melalui kepuasan kerja. Besar pengaruh budaya organisasi terhadap kinerja melalui kepuasan kerja sebesar 0,207. Gaya kepemimpinan berpengaruh terhadap kinerja melalui kepuasan kerja. Besar pengaruh gaya kepemimpinan terhadap 
kinerja melalui kepuasan kerja adalah 0,223. Ini menunjukkan bahwa kepuasan kerja menjadi intervening atau perantara budaya organisasi dan gaya kepemimpinan. Dengan demikian, kepuasan kerja merupakan variabel yang dominan dalam mempengaruhi kinerja kepala sekolah. Dari temuan terlihat bahwa nilai pengaruh budaya organisasi terhadap kepuasan kerja lebih besar daripada nilai pengaruh gaya kepemimpinan terhadap kepuasan kerja. Dengan demikian, budaya organisasi lebih dominan mempengaruhi kepuasan kerja bila dibandingkan gaya kepemimpinan. Namun, dari temuan penelitian terlihat gaya kepemimpinan lebih berpengaruh secara langsung bila dibandingkan budaya organisasi terhadap kinerja.

\section{PENUTUP}

Kesimpulan. Berdasarkan analisis terhadap hasil penelitian maka dapat disimpulkan: (1) Budaya organisasi berpengaruh langsung terhadap kepuasan kerja kepala sekolah $20,97 \%$ dengan koefisien jalur sebesar 0,458. Jadi budaya organisasi terbukti berpengaruh langsung terhadap kepuasan kerja. Dengan perkataan lain, semakin kuat budaya organisasi, makin tinggi kepuasan kerja. (2) Budaya organisasi berpengaruh langsung terhadap kinerja kepala sekolah sebesar 1,90\% dengan koefisien jalur sebesar 0,138 . Jadi budaya organisasi terbukti berpengaruh langsung terhadap kinerja. Dengan perkataan lain, semakin kuat budaya organisasi, makin tinggi kinerja kepala sekolah. (3) Gaya kepemimpinan berpengaruh langsung terhadap kepuasan kerja kepala sekolah sebesar 18,57\% dengan koefisien jalur sebesar 0,431. Jadi gaya kepemimpinan terbukti berpengaruh langsung terhadap kepuasan kerja. Dengan perkataan lain, semakin optimal gaya kepemimpinan, makin tinggi kepuasan kerja. (4) Gaya kepemimpinan berpengaruh langsung terhadap kinerja kepala sekolah sebesar 4,62\% dengan koefisien jalur sebesar 0,215. Jadi gaya kepemimpinan terbukti berpengaruh langsung terhadap kinerja. Dengan perkataan lain, semakin optimal gaya kepemimpinan, makin tinggi kinerja kepala sekolah. (5) Kepuasan Kerja berpengaruh langsung terhadap kinerja kepala sekolah sebesar 38,19

\% dengan koefisien jalur sebesar 0,1412. Jadi kepuasan kerja terbukti berpengaruh langsung terhadap kinerja kepala sekolah. Dengan perkataan lain, semakin tinggi kepuasan kerja, makin tinggi pula kinerja kepala sekolah. (6) Budaya organisasi berpengaruh tidak langsung terhadap kinerja melalui kepuasan kerja sebesar 20,76 \%. Jadi budaya organisasi terbukti berpengaruh secara tidak langsung terhadap kinerja kepala sekolah melalui kepuasan kerja. Dengan perkataan lain, semakin kuat budaya organisasi maka makin meningkat kepuasan kerja, sehingga makin baik pula kinerja kepala sekolah. (7) Gaya kepemimpinan berpengaruh secara tidak langsung terhadap kinerja kepala sekolah melalui kepuasan kerja sebesar 22,37 \%. Jadi gaya kepemimpinan terbukti berpengaruh secara tidak langsung terhadap kinerja kepala sekolah melalui kepuasan kerja. Dengan perkataan lain, semakin optimal gaya kepemimpinan, maka makin meningkat kepuasan kerja, sehingga makin baik pula kinerja kepala sekolah.

Saran. Beberapa saran bagi institusi dan perorangan untuk mewujudkan peningkatan kinerja kepala sekolah, sebagai berikut: Direktorat Jenderal Manajemen Pendidikan Dasar dan Menengah, Depdiknas. Perlu membuat trobosan menyusun kebijakan dan program kegiatan untuk peningkatan sarana dan prasarana pendidikan di Sekolah Menengah Atas agar mampu memberi dukungan kepala sekolah guna meningkatkan kepuasan kerja dan kinerjanya. Kemudian pada akhir tahun mengadakan monitoring 
dan evaluasi terhadap hasil implementasi kebijakan dan program peningkatan fasilitas pendidikan tersebut sebagai umpan balik untuk penyempurnaan. (1) Direktorat Jenderal Peningkatan Mutu Pendidik dan Tenaga Kependidikan, Depdiknas. Perlu menyusun kebijakan dan program pembinaan Kepala Sekolah sebagai upaya pengoptimalan kepemimpinan kepala sekolah, pengembangan budaya organisasi yang kuat di Sekolah, peningkatan kepuasan kerja dan peningkatan kinerja kepala sekolah seperti penyusunan rencana strategik peningkatan SDM lima tahunan termasuk pengoptimalan implementasi sertfikasi uji kompetensi, pemberian beasiswa melanjutkan pendidikan ke perguruan tinggi bagi kepala sekolah yang berprestasi, penyelenggaraan workshop dan seminar bagi tenaga pendidik. Kemudian melakukan monitoring dan evaluasi terhadap hasil implementasi kebijakan dan program pembinaan tersebut sebagai umpan balik untuk penyempurnaan. (2) Suku Dinas Pendidikan Menengah Kota Jakarta Timur. (a) Perlu membuat perencanaan strategik SDM lima tahunan yang diarahkan untuk peningkatan kualitas guru dan kepala sekolah di Jakarta Timur. Perlu memberikan penghargaan dan insentif bagi Kepala Sekolah yang berprestasi, termasuk harus memprioritaskan untuk mengikuti uji kompetensi. (b) Perlu melakukan penilaian/evaluasi kinerja untuk kepentingan pengembangan karir kepala sekolah, sebagai persyaratan promosi jabatan yang berbasis kinerja. (c) Perlu melakukan pembinaan melalui diklat kedinasan yang membahas materi berkaitan dengan leadership, budaya organisasi, kepuasan kerja. (3) Kepala Sekolah, (a) Harus memberikan suri tauladan kepada warga sekolah berupa pembudayaan loyalitas terhadap organisasi, keterlibatan terhadap setiap jenis kegiatan dan keberpihakan terhadap nilai, aturan, dan tujuan organisasi. Kemudian mengoptimalkan gaya kepemimpinan situasional untuk mempengaruhi bawahan. (b) Perlu meningkatkan pengetahuan, kemampuan terkait dengan pengembangan budaya organisasi dan leadership melalui pendidikan yang relevan . (c) Harus bekerja lebih keras dengan menerapkan aspek-aspek yang mampu meningkatkan kinerjanya, meliputi : (1) penyusunan program kerja, (2) menyelesaikan tugas dengan baik, (3) tanggap terhadap keluhan dan prestasi bawahan, (4) melakukan kerjasama yang intensif, (5) mengelola administrasi sekolah yang akurat, (6) melakukan pengawasan dan evaluasi terhadap program kerja yang telah dilaksanakan. 


\section{DAFTAR RUJUKAN}

Amstrong Michael and Angela Baron. Performance Management. London: Institute of Personnel and Development, 1998.

Anoraga Pandji. Psikologi Kerja. Jakarta: Rineka Cipta, 2001.

Bowin, Robert Bruce and D. Harvey. Human Resource Management. New York: McGrawHill, 1996.

Colquitt, LePine, Wesson Calquit, dan LePine Wesson. Organizational Behavior. Boston: McGraw-Hill, 2009.

Dole, Carol and Schroeder, Richard G. The Impact of Varios Factors on the Personality, Job Satisfaction and Turn Over Intentions of Profesional Accountants. Managerial Auditing Journal, 2001.

Gibson, James L., et al. Organizations: Behavior, Structure, Processes. New York: McGrawHill, 2006.

Handoko. Manajemen Personalia dan Sumberdaya Manusia. Jakarta: PT. Gramedia, 2000.

Hayness, Marion E. Managing Performance: A Comprehensive Guide to Effective supervision. California: Lifetime learning Publications, 1984.

Hersey Paul, Kenneth Blanchard, and Dewey E. Johnson. Managing Organizational Behavior: Utilizing Human Resources, New Jersey: Prentice Hall, Inc, 1996.

Hodgetts, Richard M. \& Donald F. Kuratko. Management. San Diego: Harcourt Brace Jovanovich Publishers, 1988.

Hugh, Arnold J. and Daniel C. Feldman. Organizational Behavior. New York: McGrawHill Book Company, 1986.

Jones, Gareth R. Organizational Behavior. Third Edition. United Stated of America Wesley: Longman Publishing Company. Inc, 2001.

Kreitner and Kinichi. Organization Theory and The New Public Administration Boston Allyn and Bacon, Inc, 2003.

Luthans, Fred. Organizational Behavior. Singapore: McGraw Hill, 2008.

Matondang M.H. Kepemimpinan, Budaya Organisasi dan Manajemen Strategik. Yogyakarta: Graha Ilmu, 2008.

Noe, Raymond A. et al. Human Resources Management. Boston: McGraw-Hill, 2000.

Rivai, Veithzal dan A. Fawzi M. Basri. Performance Appraisal. Jakarta: Grafindo Persada, 2005.

Robbins, Stephen P dan Mary Coulter. Manajemen, Jilid 2. Terjemahan Harry Slamet \& Ernawati Lestari. Jakarta: PT. Indeks, 2007.

Robbins, Stephen P. dan Timothy A. Judge. Organizational Behavior. New Jersey: McGraw-Hill, 2007.

Robbins, Stephen P. Essentials of Organization Behavior. New Jersey: Prentice Hall, Inc, 2005. 
Ruky Achmad S. Performance Management System. Jakarta: PT Gramedia Pustaka Utama, 2006.

Schein Edgar H. Organizational Culture and Leadership. San Francisco: Jossey-Bassa Publisher, 2004.

Sopiah. Perilaku Organisasi. Yogyakarta: C.V Andi Ofset, 2008.

Thoha Miftah. Perilaku Organisasi. Jakarta: PT Raja Grafindo Persada, 2001.

Tyson Shaum dan Tony Jackson. The Essence of Organizational Behavior . Terjemahkan oleh Dedy Jacobus . Yogyakarta: Andi, 2000.

Weihrich, Heinz dan Harold Koonz. Management: A global Perspective. Philippines: McGraw-Hill, 2005.

Wexley Kenneth N. and Gary A. Yukl. Organisasi Behavior and Personnel Psychology. USA: Ricard D. Irwin, Inc, 1984. 